E-ISSN. 2685-7650

Vol 3 No 2 (2021) pp 92-100

Artikel Disubmit 11 November 2021 Revisi 15 November $\bullet$ Revisi Diterima 2 Desember

\title{
Strategi Komunikasi LPP PKB dalam Pemenangan Pemilu Legislatif 2019
}

\author{
Hafidlatul Fauzuna \\ Program Studi Komunikasi dan Penyiaran Islam, IAIN Madura \\ Email: fauzunafieda@iainmadura.ac.id
}

\begin{abstract}
The 2019 legislative general election was attended by many political parties, which has implications for the tight competition for voters' votes. In this situation, the communication strategy of $P R$ or winning institutions became very important to garner public support in the form of voting. This study broadly aimed to examine the communication strategy of the PKB Election Winning Institution $(L P P)$ in the implementation of the 2019 election. The research used a descriptive qualitative approach, where data was collected through interview, observation, and documentation techniques. The results showed that the communication strategy of the PKB Election Winning Institution (LPP) in the 2019 election was to carry out image management by strengthening the relationship with Nahdliyyin clerics and conducting door-to-door communication. LPP PKB provided information, convinces the public, and arouses their interest in providing voting support for legislative candidates from PKB.
\end{abstract}

Keywords: communication strategy; public relations; general election; PKB

\begin{abstract}
Abstrak: Pemilihan umum legislatif 2019 diikuti oleh banyak partai politik, yang berimplikasi pada ketatnya persaingan perebutan suara pemilih. Dalam situasi ini strategi komunikasi Humas atau lembaga pemenangan menjadi sangat penting untuk menggalang dukungan masyarakat dalam bentuk pemberian suara. Penelitian ini secara garis besar bertujuan untuk mengkaji strategi komunikasi Lembaga Pemenangan Pemilu (LPP) PKB dalam pelaksanaan pemilu 2019. Penelitian menggunakan pendekatan kualitatif deskriptif, di mana data dikumpulkan melalui teknik wawancara, observasi, dan dokumentasi. Hasil penelitian menunjukkan bahwa strategi komunikasi Lembaga Pemenangan Pemilu (LPP) PKB dalam pelaksanaan pemilu 2019 adalah melakukan manajemen citra dengan cara mempererat tali silaturrahmi dengan para ulama Nahdliyyin dan melakukan komunikasi pintu ke pintu. LPP PKB memberikan informasi, menyakinkan masyarakat, dan membangkitkan ketertarikan mereka untuk memberikan dukungan suara pada calon-calon anggota legislatif yang berasal dari PKB.
\end{abstract}

Kata kunci: strategi komunikasi; public relations; pemilu umum; PKB

\section{Pendahuluan}

Sebagai sebuah partai, PKB memiliki tujuan jangka panjang, menengah, maupun pendek. Ketiganya merupakan satu kesinambungan. Artinya, tujuan jangka pendek mendukung pencapaian tujuan jangka menengah, tujuan jangka menengah menopang terwujudnya tujuan jangka panjang. Kesinambungan ini harus diikuti oleh proses alih generasi yang alami. Oleh sebab itu, partai politik selalu siap dengan tenaga muda dan baru untuk menjaga momentum pencapaian tujuan akhirnya. Karena itu, proses pemilihan calon anggota menjadi sangat penting bagi kelangsungan hidup partai (Gaffar, 2006).

Di Madura, sejak awal PKB mendapat dukungan penuh dari masyarakat. Di tahun 1999 dan 2004 PKB berhasil menjadi partai yang terbanyak memperoleh kursi DPRD. Di tahun 1999 PKB menjadi partai favorit masyarakat Kabupaten Sumenep seolah tidak ada partai lain 
yang bisa mewakili suara masyarakat Sumenep kecuali partai tersebut. Perolehan kursi PKB di Kabupaten Sumenep dalam pemilu legislatif dari tahun 1999-2019 sangat beragam.

Tabel 1.1 Perolehan kursi PKB di Kabupaten Sumenep dari tahun 1999-2019

\begin{tabular}{|c|c|}
\hline \multicolumn{1}{|c|}{ Tahun } & Perolehan Kursi \\
\hline 1999 & 25 kursi \\
\hline 2004 & 21 kursi \\
\hline 2009 & 11 kursi \\
\hline 2014 & 07 kursi \\
\hline 2019 & 10 kursi \\
\hline
\end{tabular}

Pada pemilihan umum anggota DPRD tahun 2014 yang diikuti oleh 12 partai politik, PKB menjadi satu-satunya partai politik peserta pemilu 2014 yang dengan tegas mencantumkan Ahlussunnah wal Jama'ah sebagai haluan perjuangannya dalam AD/ART PKB. PKB maju sebagai partai NU (Nahdlatul Ulama) dan mewakili suara warga NU yang selama ini merasa tidak puas dengan adanya partai politik lain.

Stigma yang muncul mengenai PKB adalah lembaga atau partai politik yang didirikan kaum Nahdliyin, yang jumlahnya puluhan juta di Indonesia. Pada tahun 2016, dari 223,18 juta jiwa penduduk Indonesia yang beragama Islam, 60-120 juta jiwanya adalah warga Nahdliyin (Rochim \& Kiswondari, 2018). Namun demikian, warga NU belum tentu anggota PKB, namun jelas partai itu berbeda dengan misalnya, PAN yang terkesan lebih dekat dengan warga Muhammadiyah.

Sebagai partai politik yang berbasis Islam tentu mudah bagi PKB Sumenep untuk memperoleh kepercayaan masyarakat karena mayoritas masyarakat Sumenep beraga Islam dan berasal dari kalangan Nahdliyin. Terbukti dengan perolehan kursi PKB pada pemilu 1999. Kursi yang diperoleh PKB dalam pemilu legislatif 1999 sebanyak 25 kursi dan ini menjadi bukti bahwa PKB berhasil mencuri perhatian masyarakat Sumenep. Di tahun pemilu berikutnya yaitu 2004 perolehan suara PKB menurun meski tidak terlalu jauh dengan perolehan suara sebelumnya (Wildan, 2020).

Jika diperhatikan dalam tabel tersebut sejak pemilu 2004 PKB terus mengalami penurunan perolehan suara atau kursi dikarenakan problem internal partai dan juga dipengaruhi oleh adanya partai-partai politik baru. Dengan begitu PKB berkerja lebih keras dengan memperbaharui strategi-strategi komunikasi yang disampaikan kepada masyarakat. Di PKB, yang menjalankan fungsi ini adalah Lembaga Pemenangan Pemilu (LPP). LPP memiliki tugas yang hampir sama dengan Public Relations, yaitu membangun kesan (images) positif untuk menggalang dukungan positif dari publik demi tercapainya tujuan lembaga (Natawilaga, 2018). Namun demikian, jika aktivitas Public Relations bermuara pada terciptanya citra baik sebuah lembaga, organisasi atau perusahaan di mata masyarakat (Lengkong et al., 2017), maka LPP bertugas merumuskan strategi sebuah partai politik atau pencalonan legislatif dan kepala daerah untuk dapat memenangkan kekuasaan dalam pemerintahan.

Pemilihan umum anggota legislatif tahun 2019 di Sumenep diikuti oleh banyak partai. Hal ini berakibat pada ketatnya persaingan dalam memperebutkan dukungan masyarakat. Dukungan yang dimaksud adalah pemberian hak suara mereka pada hari pemungutan suara. Ada banyak cara yang dilakukan partai politik untuk mendulang suara rakyat, mulai dari 
pembentukan citra positif lembaga maupun figur calon hingga pembentukan citra positif baik secara personal maupun secara kelembagaan. Dalam hal ini ada banyak strategi komunikasi yang bisa dilakukan partai politik, mulai dari silaturrahmi ke tokoh cendekiawan, hingga berkampanye baik secara tradisional maupun menggunakan media digital (Kaslam \& Sulistiani, 2021; Alfiyani, 2018).

Sebagai sebuah partai, PKB dibentuk karena adanya persamaan aspirasi dan persepsi politik. Partai politik dibentuk untuk menjalankan kekuasaan politik (Natalia, 2015). Tentu saja tujuan utamanya adalah untuk mengakomodasi aspirasi masyarakat untuk diproses menjadi program atau kebijakan secara lebih terstruktur (Darmawan \& Septiana, 2019). Sebetulnya, ada berbagai definisi tentang partai politik yang dikemukakan oleh para ilmuwan politik. Friedrich mendefinisikan partai politik sebagai kelompok manusia yang terorganisasikan secara stabil dengan tujuan untuk merebut atau mempertahankan kekuasaan dalam pemerintahan bagi pemimpin partainya dan berdasarkan kekuasaan itu akan memberikan kegunaan materiil dan idiil kepada para anggotanya (Budiardjo, 2008).

Sigmund Neurmann dalam Modern Political Parties mendefinisikan partai politik sebagai organisasi dari aktivis-aktivis politik yang berusaha untuk menguasai kekuasaan pemerintahan serta merebut dukungan rakyat melalui persaingan dengan suatu golongan atau golongan-golongan lain yang mempunyai pandangan berbeda (Ishaq, 2015). Partai politik adalah kelompok warga negara yang terorganisasi yang berusaha menguasai pemerintahan dengan merebut dukungan dari masyarakat. Untuk memahami peran partai politik akan lebih mudah apabila memahami terlebih dahulu fungsi dari partai politik.

Pertama, partai politik berfungsi untuk sosialisasi politik. Menurut sesorang ahli sosiologi politik M. Rush sosialisasi politik adalah proses yang melaluinya orang dalam masyarakat tertentu belajar mengenali sistem politiknya. Proses ini sedikit banyak menentukan persepsi dan reaksi mereka terhadap fenomena politik. Sosialisasi politik merupakan sebuah proses di mana seseorang memperoleh sikap dan orientasi terhadap fenomena politik yang umumnya berlaku dalam masyarakat. Sosialisasi politik partai juga dapat dipandang sebagai suatu upaya menciptakan citra bahwa ia memperjuangkan kepentingan umum. Ini penting jika dikaitkan dengan tujuan partai politik yaitu untuk menguasai pemerintahan dengan kemenangan dalam pemilihan umum. Lebih bagus dan lebih baik lagi jika partai politik dapat menjalankan fungsi sosialisasi politik untuk mendidik anggota-anggotanya agar sadar akan tanggung jawabnya sebagai warga negara dan menempatkan kepentingan pribadi di bawah kepentingan masyarakat.

Kedua, partai politik berfungsi untuk komunikasi politik. Menurut Sigmund Neumann dalam hubungannya dengan komunikasi politik, partai politik merupakan perantara besar yang menghubungkan kekuatan-kekuatan dan ideologi sosial dengan lembaga pemerintah yang resmi dan yang mengaitkannya dengan aksi politik di dalam masyarakat politik yang lebih luas. Namun tak jarang pelaksanaan fungsi politik ini menghasilkan informasi yang mengandung isuisu yang meresahkan masyarakat karena memihak salah satu kelompok (Ishaq, 2015).

Ketiga, untuk rekrutmen politik. Rekrutmen politik merupakan fungsi untuk mempersiapkan kepemimpinan internal maupun nasional karena setiap partai membutuhkan kader-kader berkualitas demi perkembangan partainya. Rekrutmen politik merupakan salah satu cara untuk menjaring dan melatih calon-calon pemimpin. Keempat, berfungsi sebagai untuk pengatur konflik politik. Menurut pendapat ahli Arend Lijphart perbedaan-perbedaan atau 
perpecahan ditingkat massa bawah dapat diatasi oleh kerjasama di antara elite-elite politik (Rahman, 2007).

Dalam konteks kepartaian, para pemimpin partai adalah elite politik. Dengan demikian, partai politik menjadi salah satu faktor penting bagi tegaknya negara demokrasi. Hal ini dikarenakan partai politik menjadi sarana mobilitas aspirasi masyarakat dan pemerintah. Selain itu partai politik menjadi sarana informasi bagi masyarakat dalam memberikan penjelasan mengenai keputusan-keputusan pemerintah yang telah disepakati. Secara ringkas partai politik dapat dikatakan sebagai penghubung antara masyarakat dengan pemerintahnya.

Untuk menyampaikan pesan-pesan politik, tentu saja juga termasuk untuk merumuskan aspirasi masyarakat, partai politik melakukannya dengan komunikasi politik yang baik. Bagi Rush dan Althoff, komunikasi politik merupakan transmisi informasi secara politis dari satu bagian sistem politik kepada sistem politik yang lain, dan antara sistem sosial dan sistem politik merupakan unsur dinamis dari suatu sistem politik (Susanto, 2017). Komunikasi politik dilihat dari dua dimensi, yaitu komunikasi politik sebagai kegiatan politik dan sebagai kegiatan ilmiah. Komunikasi sebagai kegiatan politik merupakan penyampaian pesan-pesan yang bercirikan politik oleh actor-aktor politik kepada pihak lain. Kegiatan tersebut bersifat empiris karena dilakukan secara nyata dalam kehidupan sosial. Sementara itu, komunikasi politik sebagai kegiatan ilmiah melihat komunikasi politik merupakan salah satu kegiatan politik dalam sistem politik.

Sebagai suatu bentuk kajian yang berhubungan dengan kegiatan berkomunikasi, beberapa ahli menjelaskan beberapa unsur-unsur komunikasi politik melalui beberapa sudut pandang yang berbeda-beda. Unsur komunikasi politik meliputi sumber (komunikator), pesan, media atau saluran, penerima dan efek (Cangara, 2016).

Dalam sebuah lembaga partai, selain figur, yang terlibat aktif dalam melakukan komunikasi politik adalah Public Relations atau Humas partai. Komunikasi politik tidak dilakukan begitu saja, melainkan disampaikan melalui strategi-strategi tertentu. Dalam hal ini berarti ada dua aspek yang perlu diparhatikan, yaitu strategi dan Humas atau Public Relations. Menurut Efendy, strategi merupakan perencanaan (planning) dan manajemen untuk mencapai tujuan (Setyawati, 2017). Sedangkan Public Relations atau Humas, menurut Cutlip-CenterBroom, didefinisikan sebagai usaha yang terencana untuk memengaruhi pandangan melalui karakter yang baik serta tindakan yang bertanggung jawab, didasarkan atas komunikasi dua arah yang saling memuaskan (Morrison, 2008). Majelis Humas Dunia (World Assembly Of Public Relations) mendefinisikan Humas sebagai seni dan ilmu sosial dalam menganalisis kecenderungan, memerkirakan akibat-akibat, memberikan saran kepada pimpinan perusahaan atau lembaga serta melaksanakan program tindakan terencana yang melayani baik kepentingan organisasi dan khalayaknya (Morrison, 2008).

Menurut Jefkins, Humas merangkum keseluruhan komunikasi yang terencana, baik itu ke dalam maupun keluar antara suatu organisasi dengan semua khalayaknya dalam rangka mencapai tujuan-tujuan spesifik yang berlandaskan pada saling pengertian (Ishaq, 2015). Dapat dipahami, strategi Humas atau yang dalam PKB menggunakan akronim LPP adalah segala langkah atau program yang dilakukan oleh divisi LPP untuk mencapai tujuan partai sesuai dengan perencanaan organisasi atau lembaga.

Ada beberapa hal yang perlu diperhatikan seorang Public Relations dalam membina hubungan dengan Public Relations internal atau masyarakat yang berhubungan dengan 
organisasi atau lembaga. Pertama, hubungan pemimpin dengan anggotanya, yaitu bagaimana seorang pemimpin dalam sebuah perusahaan atau organisasi dalam berkomunikasi dengan anggotanya sehingga bisa menciptakan komunikasi yang efektif. Kedua, hubungan anggota dengan bawahan, yakni bagaimana seharusnya sikap seorang anggota kepada pemimpinnya dalam sebuah perusahaan atau lembaga. Ketiga, hubungan dengan sesama pekerja, yaitu bagaimana komunikasi atau interaksi yang terjalin antar sesama anggota dalam sebuah organisasi atau lembaga. Sedangkan dalam Public Relations eksternal atau yang dikenal masyarakat dengan sesuatu yang berhubungan dengan sebuah perusahaan. Public Relations eksternal menjalin hubungan atau komunikasi dengan orang-orang di luar perusahaan atau lembaganya.

Dalam menjalankan tugasnya, seorang Public Relations membutuhkan berbagai cara yang digunakan untuk mencapai tujuan sebuah organisasi atau lembaga yang telah ditetapkan. Selain sebagai pembentuk opini publik, seorang Humas atau Public Relations juga sebagai mediator yang menjembatani kepentingan perusahaan atau lembaganya dengan khalayak. Oleh karena itu, Fayol menyebutkan beberapa kegiatan dan sasaran Public Relations. Pertama, membangun identitas dan citra perusahaan. Kedua, menciptakan identitas dan citra perusahaan yang positif. Ketiga, mendukung kegiatan komunikasi timbal balik dua arah dengan berbagai pihak. Keempat, menghadapi krisis dan menangani keluhan dalam menghadapi krisis yang terjadi dengan membentuk manajemen krisis dan Public Relations recovery of image overy (pemulihan citra) yang bertugas memperbaiki lost image and damage (kehilangan dan kerusakan citra) (Ishaq, 2015).

Seorang praktisi Humas sebuah organisasi atau lembaga tentu membutuhkan bantuan media untuk mendapatkan kepercayaan masyarakat dan menciptakan citra baik di publik, baik media sosial atau media bantuan lainnya seperti alat peraga kampanye. Public Relations atau LPP PKB juga menggunakan beberapa media sosial untuk menciptakan citra baik di masyarakat. Beberapa media yang digunakan oleh Public Relations PKB di antaranya Facebook, Youtube, dan Blog. Selain media sosial, Public Relations PKB juga menggunakan media bantuan lainnya berupa alat peraga kampanye seperti baliho, banner dan bendera.

\section{Metode Penelitian}

Penelitian ini menggunakan pendekatan kualitatif. Pendekatan kualitatif merupakan metode penelitian yang sistematis digunakan untuk mengkaji atau meneliti suatu objek pada latar alamiah tanpa ada manipulasi didalamnya dan tanpa ada pengujian hipotesis, dengan metodemetode yang alamiah ketika hasil penelitian yang diharapkan bukanlah generalisasi berdasarkan ukuran-ukuran kuantitas, namun makna dari fenomena yang diamati.

Dalam penelitian kualitatif ini lebih menonjolkan terhadap perspektif subjektif dalam menggali makna. Semakin dalam dan detail data yang didapatkan, maka semakin baik pula kualitas dari penelitian kualitatif. Adapun jenis penelitian yang digunakan adalah jenis penelitian deskriptif. Penelitian deskriptif merupakan suatu rumusan masalah yang memandu penelitian untuk mengeksplorasi atau memotret situasi yang akan diteliti secara menyeluruh, luas, dan mendalam (Sadjah, 2015). Penelitian deskriptif berusaha untuk mengungkapkan serta memaparkan fakta yang terjadi di lapangan dan menganalisis data yang didapatkan yang kemudian dikaitkan dengan sikap atau pandangan masyarakat.

Data dalam penelitian ini dikumpulkan melalui teknik wawancara mendalam kepada narasumber yang ada di PKB, mulai dari Ketua Dewan Syuro, sekretaris Dewan Syuro, Ketua 
Tanfidz DPC PKB, sekretaris Tanfidz DPC PKB, sekretaris Lembaga Pemenangan Pemilu (LPP) 2019, Ketua DPRD Sumenep, hingga anggota DPRD Sumenep. Selain daripada itu data juga dikumpulkan melalui teknik observasi dan dokumentasi. Data-data yang sudah terkumpul kemudian dianalisis menggunakan dua tahapan, yaitu checking (pengecekan) dan organizing (pengelompokan). Pengecekan berarti memeriksa kembali transkrip data wawancara, observasi dan dokumentasi untuk mengetahui kelengkapan data yang dibutuhkan. Sedangkan pengelompokan data dilakukan untuk memudahkan peneliti dalam menggabungkan, menganalisis serta menyimpulkan data yang diperoleh.

\section{Hasil dan Pembahasan}

\section{Strategi Komunikasi LPP PKB dalam Pemenangan Pemilu Legislatif 2019}

Suatu organisasi atau lembaga membutuhkan seorang Public Relations atau Humas. Public Relations tentu memiliki peran dan fungsi dalam organisasi untuk menjalankan dan mendukung program kerja yang telah disepakati bersama. Public Relations memiliki peranan yang penting bagi suatu organisasi atau perusahaan, yakni sebagai perwakilan organisasi kepada publiknya dan perwakilan publik kepada organisasi. Seorang Humas harus mengetahui alasan dari setiap keputusan dan tindakan yang diambil. Dengan begitu ia dapat merencanakan dan merancang komunikasi yang efektif untuk memberikan informasi kepada masyarakat luas.

Sebuah perusahaan atau organisasi yang memiliki Humas pasti membutuhkan suatu strategi untuk mengimplementasikannya. Suatu strategi dapat meningkatkan komunikasi dua arah antara lembaga dengan sasaran yang dituju, sehingga dapat berpatisipasi dalam mewujudkan tujuan lembaga atau organisasinya. Sesuai dengan kinerja Public Relations di mana dalam melakukan perencanaan kerja, kegiatan atau program, harus diawali dan diakhiri dengan riset.

Pada umumnya dalam merencanakan suatu kegiatan atau program dalam sebuah organisasi memerlukan Public Relations sebagai jembatan penghubung antara pihak internal maupun eksternal. Berdasarkan situasi yang ada, partai yang didirikan pada tanggal 23 Juli 1998 ini telah mengikuti pesta demokrasi sebanyak lima kali. Untuk tercapainya tujuan PKB dalam pemilu diperlukan adanya strategi komunikasi Public Relations. Partai melakukan publikasi dan promosi yang dilakukan oleh Humas yang memang memiliki tanggung jawab cukup besar dalam menjalankan strategi komunikasi untuk pemenangan. Meski sampai saat ini partai PKB belum memiliki divisi khusus Public Relations, namun hal tersebut untuk sementara bisa diatasi dengan adanya LPP.

Selama ini, strategi Public Relations yang dijalankan oleh LPP dalam partai PKB Sumenep dalam membangun citra positif partai dapat dikaitkan dengan Public Relations politik. Hal ini sejalan dengan teori yang membagi peran Public Relations politik ke dalam empat bagian, yaitu, manajemen informasi, manajemen media, manajemen citra, dan komunikasi internal (Dea, 2018). Peran ini sejalan dengan teori Sam Black and Melvin L, Sharpe yang menyebutkan bahwa saran untuk penampilan organisasi demi citranya di masyarakat (Ishaq, 2015).

Strategi yang dilakukan PKB adalah manajemen citra yang dilakukan dengan cara mempererat tali silaturrahmi dengan para ulama Nahdliyin dan melakukan door to door communication atau komunikasi pintu ke pintu. Manajemen citra sudah seperti sebuah eharusan bagi PKB sebagai partai politik yang masih mempertahankan politik kultural. 
Walaupun PKB termasuk salah satu partai yang sudah lama berkecimpung dalam dunia perpolitikan, PKB tetap memperkenalkan diri kepada masyarakat dengan hal-hal yang baru.Menurut Mcnair, aktivitas seperti ini dapat dilakukan melalui pembuatan logo, slogan, pengarahan gaya foto, perancangan iklan, serta pemilihan bahasa dalam mengkomunikasikan ide maupun kebijakan (Dea, 2018).

Mayoritas peran manajemen citra dilakukan pada penempatan pesan di media seperti wawancara politik serta kampanye di ruang publik. Walaupun PKB belum memaksimalkan apa yang seharusnya dilakukan sebagai partai politik. Manajemen informasi dan manajemen media yang belum maksimal dijalankan oleh PKB adalah hal yang sangat penting dalam sebuah perjalanan partai politik dalam mengikuti pesta demokrasi. Seharusnya manajemen informasi dan manajemen media menjadi tombak untuk menciptakan citra positif. Hal ini sejalan dengan empat model Public Relations yang dikemukakan Grunig dan Hunt, yaitu press agentry/publicity model, public information model, two way asymmetric model, dan two way symmetric model (Chotimah, 2014). Namun, mengenai estimasi penerapan empat model dalam sebuah organisasi yang paling banyak digunakan adalah model public information sebanyak 50\%, 20\% press agentry, 15\% two-way asymmetric dan two-way symmetric (Grunig, 1992).

Partai PKB merupakan partai besar di Indonesia, di mana anggota partai terdiri dari berbagai macam latar belakang dan pengalaman politik berbeda sehingga komunikasi internal bermanfaat untuk merajut kebersamaan dan kesatuan antar anggota. Sebagai bagian dari organisasi, Public Relations wajib mendukung keberadaan divisi lain dalam partai. Untuk mempererat kebersamaan dan kesatuan antar anggota, diperlukan interaksi dan kerjasama agar setiap anggota dapat saling mengenal dan mengakrabkan diri satu sama lain.

Meski sejauh ini PKB belum memiliki divisi khusus Public Relations, yang menjadi menarik dari partai PKB adalah bisa mendapatkan suara atau kursi tertinggi di Kabupaten Sumenep. Sepanjang mengikuti pemilihan umum di Indonesia khususnya di Kabupaten Sumenep PKB selalu menjadi salah satu partai yang menjadi pilihan masyarakat. Hal ini berkaitan dengan strategi yang dilakukan PKB. Dua strategi yang digunakan PKB tidak pernah berubah sejak dulu. Ini membuktikan bahwa PKB adalah salah satu partai besar yang diperhitungkan di Kabupaten Sumenep.

Sebagai partai yang masih berpegang pada politik kultural, PKB terus menggalakkan hubungan baik dengan para ulama. Di Sumenep para ulama memiliki banyak santri dan wali santri. Hubungan ini menjadi fokus utama dari PKB dengan cara tetap menjalin hubungan tali silaturrhami dengan mereka karena kekuasaan ulama pada santri dan wali santri masih sangat kuat. Biasanya, masyarakat akan mengikuti opini yang dikembangkan para ulama sebagai opinion leader, termasuk dalam hal ini dalam pemilihan umum anggota legislatif (Sugiana et al., 2019). Ini memperlihatan demokratisasi yang masih cenderung oligarkis, di mana masyarakat kalangan bawah masih didominasi oleh kalangan elit (Muaddab, 2015). Bagi kalangan masyarakat Madura, Kiai atau Ulama lebih penting daripada tokoh masyarakat yang datang dari kalangan bangsawan maupun birokrat (Ayatillah, 2020).

Jika dianalisa lebih jauh dua strategi yang terus dipertahankan oleh PKB adalah komposisi yang kurang sempurna. Hal ini terutama jika mempertimbangkan empat model Public Relations dari Grunig dan Hunt. Jika divisi khusus Public Relations ada dalam PKB dan menjalankan strategi komunikasi dengan menggunakan pendekatan empat model yang diajukan Grunig dan Hunt tentu akan menghasilkan sesuatu yang lebih besar dan menjadikan PKB sebagai partai yang besar lantarn memiliki masyarakat yang mandiri secara opini. Karena 
semakin ke depan tentu zaman akan semakin maju dengan inovasi-inovasi yang lebih cemerlang, ini juga menjadi tantangan bagi Public Relations partai politik yang harus mengikutiperkembangan zaman, di mana generasi muda mulai mengembangkan pemikiran dan keputusannya sendiri-sendiri dalam memilih pemimpin.

Di masa yang akan datang teknologi juga akan semakin maju, yang mengharuskan sebuah partai politik juga memiliki inovasi dengan mengikuti perkembangan tersebut dengan tidak hanya mengandalkan politik kultural tetapi juga harus bisa berkomunikasi dengan masyarakat melalui media sosial. Public Relations partai politik harus memiliki mempersiapkan inovasi baru bagi partai politiknya untuk menghadapi era 4.0. Begitu pun dengan partai PKB yang belum memiliki divisi khusus PKB, harus mulai berfikir bahwa sebuah organisasi atau perusahaan haruslah memiliki seorang Public Relations untuk menjadi perantara antara organisasinya dengan masyarakat.

\section{Kesimpulan}

Strategi yang dilakukan oleh PKB hanyalah manajemen citra dengan mempererat silaturrahmi dengan para ulama Nahdliyin dan melakukan komunikasi door to door atau pintu ke pintu. Manajemen citra sudah seperti sebuah keharusan bagi PKB sebagai partai politik yang masih mempertahankan politik kultural. Manajemen citra dalam bentuk lain mayoritas dilakukan pada penempatan pesan di media seperti wawancara politik serta kampanye di ruang publik. Walaupun demikian, manajemen informasi dan manajemen media yang dijalankan LPP PKB belum maksimal padahal ini sangat penting dalam sebuah perjalanan partai politik terutama ketika mengikuti pemilihan umum. Manajemen informasi dan manajemen media perlu menjadi medium utama untuk menciptakan citra positif baik lembaga partai maupun figur yang akan bertarung dalam pemilihan untuk mengurangi oligakisitas dalam demokrasi.

\section{Daftar Pustaka}

Alfiyani, N. (2018). Media Sosial Sebagai Strategi Komunikasi Politik. Potret Pemikiran, 22(1), 57-69. https://doi.org/10.30984/pp.v22i1.762

Ayatillah, I. L. (2020). Bersinar di Pergantian Abad:Menguatnya Otoritas Kiai di SumenepAkhir Abad XIX Hingga Awal Abad XX. Proceedings of 4th International Conference on Islamic Studies (ICONIS) 2020, 27-34.

Budiardjo, M. (2008). Dasar-dasar Ilmu Politik. Gramedia Pustaka Utama.

Cangara, H. (2016). Komunikasi Politik Konsep, Teori, dan Strategi. PT. Raja Grafindo Persada.

Chotimah, C. (2014). Strategi Public Relations Pesantren Sidogiri dalam Membangun Citra Lembaga Pendidikan Islam. ISLAMICA: Jurnal Studi Keislaman, 7(1), 186-210. https://doi.org/10.15642/islamica.2012.7.1.186-210

Darmawan, E., \& Septiana, A. (2019). Analisis Fungsi Partai Politik Pada Pilkada Musi Banyuasin 2017 (Studi Terhadap Partai Politik Pengusung Pasangan Dodi Reza Dan Beni Hernedi). Jurnal Studi Sosial Dan Politik, 3(1), 28-41.

Dea, K. A. (2018). Strategi Humas Partai Perindo Dalam Membangun Citra Partai. Universitas Prof. Dr. Moestopo.

Gaffar, A. (2006). Politik Indonesia. Pustaka Pelajar.

Grunig, J. E. (1992). Excellence In Public Relations And Communication Management.

Ishaq, R. El. (2015). Kuliah Public Relations. STAIN Kediri Press.

Kaslam, K., \& Sulistiani, K. (2021). Strategi Komunikasi Politik Partai Gelora Sulawesi Selatan di Masa Pandemi Covid-19. Vox Populi, 3(2), 118. https://doi.org/10.24252/vp.v3i2.18346

Lengkong, S. L., Sondakh, M., \& Londa, J. . (2017). Strategi Public Relations Dalam Pemulihan 
Citra Perusahaan (Studi Kasus Rumah Makan Kawan Baru Megamas Manado). Acta Diurna, VI(1), 1-46.

Morrison. (2008). Manajemen Public Relations. Media Grafika.

Muaddab, H. (2015). Nahdlatul Ulama' Sebagai Opinion Leader Dalam Politik Demokrasi di Indonesia (Sebuah Kajian Teoritik). Jurnal Politika, 1(1), 14-40.

Natalia, A. (2015). Peran Partau Politik Dalam Mensukseskan Pilkada Serentak di Indonesia Tahun 2015. Jurnal TAPIs, 11(1), 47-68.

Natawilaga, S. (2018). Peran Etika Dalam Meningkatkan Efektivitas Pelaksanaan Public Relations. WACANA, Jurnal Ilmiah Ilmu Komunikasi, 17(1), 64-71. https://doi.org/10.32509/wacana.v17i1.492

Rahman, A. (2007). Sistem Politik Indonesia. Graha Ilmu.

Rochim, A., \& Kiswondari. (2018). Basis Suara NU Jadi Rebutan. Sindonews.Com. https://nasional.sindonews.com/berita/1358886/12/basis-suara-nu-jadirebutan?showpage=all

Sadjah, D. (2015). Metode Peneitian Dakwah. PT. Remaja Rosdakarya.

Setyawati, D. (2017). Strategi Public Relations Dalam Mempertahankan Citra Halal Tourism Di Syariah Hotel Solo. IAIN Surakarta.

Sugiana, D., Mirawati, I., \& Trulline, P. (2019). Peran Ulama Sebagai Opinion Leader di Pedesaan dalam Menghadapi Informasi Hoaks. Avant Garde, 7(1), 1-18. https://doi.org/10.36080/avg.v7i1.848

Susanto, E. H. (2017). Jokowi's Political Communication in Jakarta Governor Electionto Win Age Based Voters. Mediterranean Journal of Social Sciences, 8(7), 312-321. 